SELLING DIVERSITY 
This page intentionally left blank 


\section{SELLING DIVERSITY}

Immigration, Multiculturalism, Employment Equity, and Globalization

$\bullet \bullet$

Yasmeen Abu-Laban

Christina Gabriel

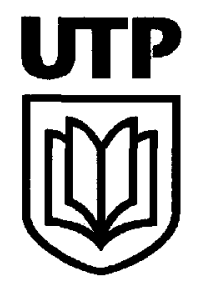


All rights reserved. The use of any part of this publication reproduced, transmitted in any form or by any means, electronic, mechanical, photocopying, recording, or otherwise, or stored in a retrieval system, without prior written consent of the publisher-or in the case of photocopying, a licence from CANCOPY (Canadian Copyright Licensing Agency), One Yonge Street, Suite 1900, Toronto, Ontario MSE IES-is an infringement of the copyright law.

Originally published by Broadview Press 2002

NATIONAL LIBRARY OF CANADA CATALOGUING IN PUBLICATION DATA

Abu-Laban, Yasmeen, I966-

Selling diversity: immigration, multiculturalism, employment equity, and globalization/Yasmeen Abu-Laban, Christina Gabriel.

Includes bibliographical references and index.

ISBN 978-1-44260-072-0

1. Canada-Emigration and immigration-Government policy.

2. Canada-Emigration and immigration--Economic aspects.

3. Multiculturalism-Canada. 4. Multiculturalism-Economic aspects-Canada.

5. Affirmative action programs-Economic aspects-Canada.

6. Globalization-Economic aspects-Canada I. Gabriel, Christina, 196I-

II. Title.

FGIO4.A28 2002

$305^{\prime} .0971$

C2002-902398-X

FIO3SAIA28 2002

North America

5201, Dufferin Street

North York, Ontario, Canada M3H 5 T8

New-York, USA 14150

Têl.: (416) 978-2239 ; Fax.: (416)978-4738

www.utphighereducation.com

Customerservice@utphighereducation.com
United Kingdom and Europe

Plymbridge North (Thomas Lyster Ltd.)

Units 3 \& 4a Ormskirk Industrial Park, Old Boundary Way, Burscough Rd,

Omskirk, Lancashire $\mathrm{L} 392 \mathrm{YW}$ TEL (1695) S75112; FAX (I695) \$70120; E-MAIL books@tlyster.co.uk

Higher Education University of Toronto Press gratefully acknowledges the support of the Ministry of Canadian Heritage throught the Book Publishing Industry Development Program

Cover design by Zack Taylor and Liz Broes.

Typeset by Liz Broes, Black Eye Design.

Printed in Canada

I0 $\begin{array}{llllllll}9 & 8 & 7 & 6 & 5 & 4 & 3\end{array}$. 
To Claude Couture and Zachary Jericho Couture, with love. Y A-L

To William Walters, with love.

CG 
This page intentionally left blank 